Article

\title{
Disulfide Competition for Phosphine Gold(I) Thiolates: Phosphine Oxide Formation vs. Thiolate Disulfide Exchange
}

\section{Gamage S. P. Garusinghe, S. Max Bessey, Mostapha Aghamoosa, Meaghan McKinnon,} Alice E. Bruce * and Mitchell R. M. Bruce *

Department of Chemistry, University of Maine, Orono, ME 04469-5706, USA;

E-Mails: gamage.garusinghe@umit.maine.edu (G.S.P.G.);

stanley.bessey@umit.maine.edu (S.M.B.); mostapha.aghamoosa@gmail.com (M.A.);

mckinnonme7@gmail.com (M.M.)

* Authors to whom correspondence should be addressed; E-Mails: abruce@maine.edu (A.E.B.); mbruce@maine.edu (M.R.M.B.); Tel.: +1-207-581-1182 (A.E.B.); +1-207-581-1190 (M.R.M.B.); Fax: +1-207-581-1191 (A.E.B. \& M.R.M.B.).

Academic Editor: Antonio Laguna

Received: 19 November 2014 / Accepted: 9 February 2015 / Published: 27 February 2015

\begin{abstract}
Phosphine gold(I) thiolate complexes react with aromatic disulfides via two pathways: either thiolate-disulfide exchange or a pathway that leads to formation of phosphine oxide. We have been investigating the mechanism of gold(I) thiolate-disulfide exchange. Since the formation of phosphine oxide is a competing reaction, it is important for our kinetic analysis to understand the conditions under which phosphine oxide forms. ${ }^{1} \mathrm{H}$ and ${ }^{31} \mathrm{P}\left\{{ }^{1} \mathrm{H}\right\} \mathrm{NMR}$, and GC-MS techniques were employed to study the mechanism of formation of phosphine oxide in reactions of $R_{3} \mathrm{PAu}\left(\mathrm{S} R^{\prime}\right)\left(R=\mathrm{Ph}, \mathrm{Et} ; \mathrm{S} R^{\prime}=\mathrm{SC}_{6} \mathrm{H}_{4} \mathrm{CH}_{3}\right.$, $\mathrm{SC}_{6} \mathrm{H}_{4} \mathrm{Cl}, \mathrm{SC}_{6} \mathrm{H}_{4} \mathrm{NO}_{2}$, or tetraacetylthioglucose (TATG)) and $R^{*} \mathrm{SS} R^{*}\left(\mathrm{~S}^{*}=\mathrm{SC}_{6} \mathrm{H}_{4} \mathrm{CH}_{3}\right.$, $\mathrm{SC}_{6} \mathrm{H}_{4} \mathrm{Cl}, \mathrm{SC}_{6} \mathrm{H}_{4} \mathrm{NO}_{2}$, or $\left.\mathrm{SC}_{6} \mathrm{H}_{3}(\mathrm{COOH})\left(\mathrm{NO}_{2}\right)\right)$. The phosphine oxide pathway is most significant for disulfides with strongly electron withdrawing groups and in high dielectric solvents, such as DMSO. Data suggest that phosphine does not dissociate from gold(I) prior to reaction with disulfide. 2D $\left({ }^{1} \mathrm{H}-{ }^{1} \mathrm{H}\right)$ NMR ROESY experiments are consistent with an intermediate in which the disulfide and phosphine gold(I) thiolate are in close proximity. Water is necessary but not sufficient for formation of phosphine oxide since no phosphine oxide forms in acetonitrile, a solvent, which frequently contains water.
\end{abstract}


Keywords: phosphine gold(I) thiolate; thiolate disulfide exchange; phosphine oxide; ROSEY 2D NMR

\section{Introduction}

Thiol-disulfide exchange reactions are essential for a number of biochemical transformations. The mechanism of this reaction in solution (in the absence of metals) is described as $\mathrm{S}_{\mathrm{N}} 2$ between thiolate and disulfide [1,2]. We have been studying how metals, such as a phosphine gold(I) thiolate complexes, alter the mechanistic reaction pathways for thiol-disulfide exchange. Our work to date has shown that the phosphine gold(I) thiolate-disulfide exchange reaction is overall second order; first order in gold-thiolate and first order in disulfide (see Equation (1)) [3-5]. The initial products of exchange are the unsymmetrical disulfide (i.e., $R^{*} \mathrm{SS} R^{\prime}$ ) and a new gold-thiolate complex (i.e., $R_{3} \mathrm{PAuS} R^{*}$ ). In a second step, the unsymmetrical disulfide reacts with the gold-thiolate starting material forming the symmetrical disulfide ( $R^{\prime} \mathrm{SS} R^{\prime}$ ) (see Equation (2)). Furthermore, neither free thiolate nor gold(III) (from possible oxidative addition of disulfide) [6] appear to be involved in the reaction.

$$
\begin{aligned}
R_{3} \mathrm{PAuS} R^{\prime}+R^{*} \mathrm{SS} R^{*} & \rightleftarrows R_{3} \mathrm{PAuS}^{*}+R^{*} \mathrm{SS}^{\prime} \\
R_{3} \mathrm{PAuS} R^{\prime}+R^{*} \mathrm{SS} R^{\prime} & \rightleftarrows R_{3} \mathrm{PAuS}^{*}+R^{\prime} \mathrm{SS}^{\prime}
\end{aligned}
$$

Our focus has been on understanding how the phosphine and thiolate ligands, disulfide, and solvent influence the kinetics of the exchange reaction. During the course of exchange studies, we have found that the nature of the solvent has a profound effect on the outcome of the reaction. When the reaction is carried out in solvents of low dielectric constant (e.g., methylene chloride), thiolate-disulfide exchange is clean but occurs very slowly (e.g., hours to days timescale). In solvents with higher dielectric constants (e.g., acetonitrile), thiolate-disulfide exchange is faster (e.g., min to hours timescale).

We have reported our preliminary findings on exchange reactions [3-5,7-10], but several issues to date have complicated the data analysis. One has been trace impurities in certain solvents that persist at the low $\mathrm{mM}$ concentration and complicate kinetic analysis when metal thiolate disulfide exchange reactions are studied at $\mu \mathrm{M}$ to $\mathrm{mM}$ concentrations. This issue will be reported separately [11]. The other issue has been a competing reaction leading to formation of phosphine oxide and a bis-thiolate gold(I) complex. The production of phosphine oxide becomes evident when the exchange reactions in high dielectric solvents are monitored for longer periods of time. We report here a series of experiments conducted to investigate reaction of disulfide with phosphine gold(I) thiolates in order to gain mechanistic insight into the competing pathways of gold(I) thiolate-disulfide exchange and phosphine oxide formation.

\section{Results and Discussion}

\subsection{Phosphine Oxide Formation in DMSO}

Reactions of $\mathrm{Ph}_{3} \mathrm{PAu}\left(\mathrm{SC}_{6} \mathrm{H}_{4} \mathrm{CH}_{3}\right)$ and $\left(\mathrm{SC}_{6} \mathrm{H}_{4} \mathrm{NO}_{2}\right)_{2}$ were monitored by using ${ }^{1} \mathrm{H}$ and ${ }^{31} \mathrm{P}$ NMR spectroscopy. We observed formation of $R_{3} \mathrm{P}=\mathrm{O}$ in DMSO and DMF, but not in tetrahydrofuran, methylene chloride, acetone, or acetonitrile. We investigated the reaction in DMSO in more detail to 
determine the influence of the phosphine, thiolate and disulfide on the amount of phosphine oxide formed. The reactions of four phosphine gold(I) thiolates $(10 \mathrm{mM})$ with four disulfides $(10 \mathrm{mM})$ were carried out in DMSO- $d_{6}$ and monitored by ${ }^{31} \mathrm{P}\left\{{ }^{1} \mathrm{H}\right\}$ NMR for $12 \mathrm{~h}$. The results are plotted in Figure 1A-D for reactions of $\mathrm{Ph}_{3} \mathrm{PAuSC}_{6} \mathrm{H}_{4} \mathrm{CH}_{3}, \mathrm{Ph}_{3} \mathrm{PAuSC}_{6} \mathrm{H}_{4} \mathrm{Cl}, \mathrm{Ph}_{3} \mathrm{PAuSC}_{6} \mathrm{H}_{4} \mathrm{NO}_{2}$, and Et ${ }_{3} \mathrm{PAuTATG}$ (auranofin), respectively. The percentage of $R_{3} \mathrm{P}=\mathrm{O}$ was calculated from the ratio of integrals for $R_{3} \mathrm{P}=\mathrm{O}$ (at $26.5 \mathrm{ppm}$ for $R=\mathrm{Ph}$ or $50.8 \mathrm{ppm}$ for $R=\mathrm{Et}$ ) and $R_{3} \mathrm{PAuS} R^{\prime}$ (at $39.2 \mathrm{ppm}$ for $R=\mathrm{Ph}$ or $40.3 \mathrm{ppm}$ for auranofin). These are the only two signals observed in the ${ }^{31} \mathrm{P}$ NMR spectra during the course of each reaction. Table 1 lists the reactions in decreasing order of extent of phosphine oxide formation at the $75 \mathrm{~min}$. time point for each combination shown in Figure 1. The results show that disulfides with more strongly electron withdrawing groups [DTNB and $\left(\mathrm{SC}_{6} \mathrm{H}_{4} \mathrm{NO}_{2}\right)_{2}$ ] produce more phosphine oxide. Electron withdrawing groups on the thiolate ligands also increase the extent of $R_{3} \mathrm{P}=\mathrm{O}$ formation. However the nature of the disulfide appears to have a larger effect. We have noted some variability in reaction rates with different batches of DMSO- $d_{6}$, which may originate from differences in water content in the solvent. The experimental results reported in Table 1 were obtained employing the same batch of DMSO- $d_{6}$ solvent.

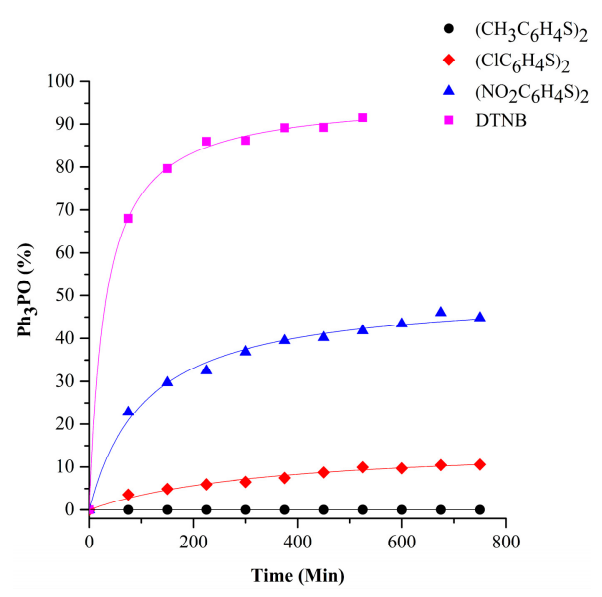

(A)

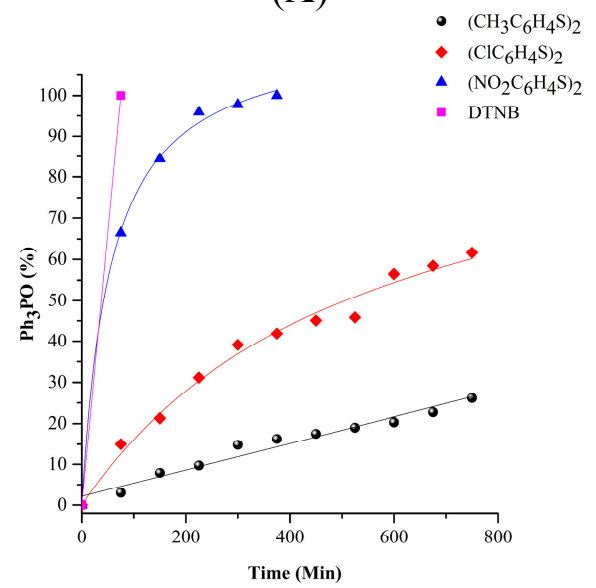

(C)

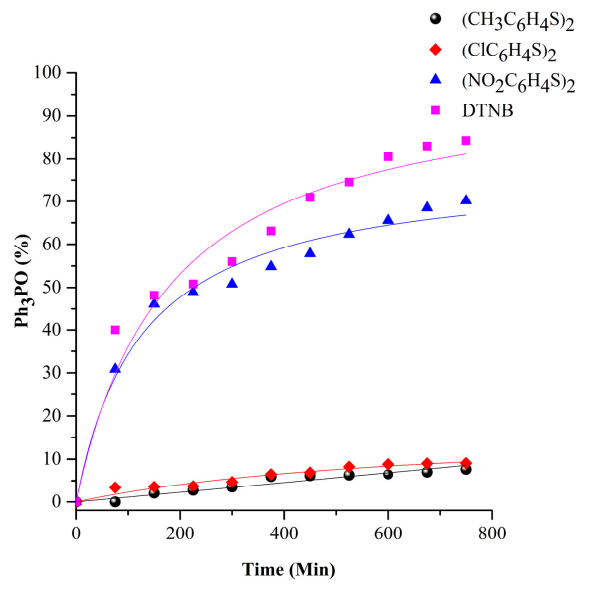

(B)

- $\left(\mathrm{CH}_{3} \mathrm{C}_{6} \mathrm{H}_{4} \mathrm{~S}\right)_{2}$

- $\left(\mathrm{ClC}_{6} \mathrm{H}_{4} \mathrm{~S}\right)_{2}$

- $\left(\mathrm{NO}_{2} \mathrm{C}_{6} \mathrm{H}_{4} \mathrm{~S}\right)_{2}$

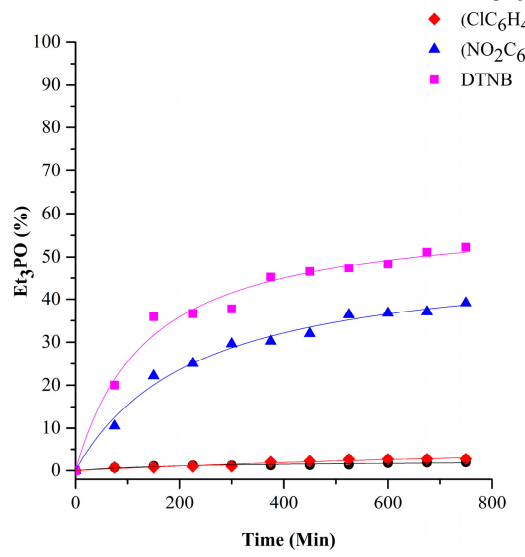

(D)

Figure 1. Formation of $\mathrm{R}_{3} \mathrm{PO}$ in DMSO- $d_{6}$ during reaction of $10 \mathrm{mM}$ disulfides with $10 \mathrm{mM}$ (A) $\mathrm{Ph}_{3} \mathrm{PAu}\left(\mathrm{SC}_{6} \mathrm{H}_{4} \mathrm{CH}_{3}\right)$; (B) $\mathrm{Ph}_{3} \mathrm{PAu}\left(\mathrm{SC}_{6} \mathrm{H}_{4} \mathrm{Cl}\right)$; (C) $\mathrm{Ph}_{3} \mathrm{PAu}\left(\mathrm{SC}_{6} \mathrm{H}_{4} \mathrm{NO}_{2}\right)$; (D) $\mathrm{Et}_{3} \mathrm{PAu}(\mathrm{TATG})$ (auranofin). The percentage of $\mathrm{R}_{3} \mathrm{PO}$ was calculated as the ratio of $\mathrm{R}_{3} \mathrm{PO}$ to the total phosphorus in the ${ }^{31} \mathrm{P}\left\{{ }^{1} \mathrm{H}\right\}$ NMR. 
Table 1. Comparison of the percentage of $\mathrm{R}_{3} \mathrm{P}=\mathrm{O}$ formed from the reaction of $10 \mathrm{mM}$ $\mathrm{P} R 3{ }_{3} \mathrm{AuS} R^{\prime}$ and $10 \mathrm{mM} R^{*} \mathrm{SSS} R^{*}$ in $\mathrm{DMSO}-d_{6}(t=75 \mathrm{~min})$.

\begin{tabular}{|c|c|c|}
\hline$R_{3}$ PAuSR' & $R * \mathrm{SS} R^{*}$ & $\mathrm{R}_{3} \mathrm{P}=\mathrm{O}(\%)$ \\
\hline $\mathrm{Ph}_{3} \mathrm{PAuSC}_{6} \mathrm{H}_{4} \mathrm{NO}_{2}$ & DTNB $^{1}$ & 100 \\
\hline $\mathrm{Ph}_{3} \mathrm{PAuSC}_{6} \mathrm{H}_{4} \mathrm{CH}_{3}$ & DTNB & 68 \\
\hline $\mathrm{Ph}_{3} \mathrm{PAuSC}_{6} \mathrm{H}_{4} \mathrm{NO}_{2}$ & $\left(\mathrm{SC}_{6} \mathrm{H}_{4} \mathrm{NO}_{2}\right)_{2}$ & 67 \\
\hline $\mathrm{Ph}_{3} \mathrm{PAuSC}_{6} \mathrm{H}_{4} \mathrm{Cl}$ & DTNB & 40 \\
\hline $\mathrm{Ph}_{3} \mathrm{PAuSC}_{6} \mathrm{H}_{4} \mathrm{Cl}$ & $\left(\mathrm{SC}_{6} \mathrm{H}_{4} \mathrm{NO}_{2}\right)_{2}$ & 31 \\
\hline $\mathrm{Ph}_{3} \mathrm{PAuSC}_{6} \mathrm{H}_{4} \mathrm{CH}_{3}$ & $\left(\mathrm{SC}_{6} \mathrm{H}_{4} \mathrm{NO}_{2}\right)_{2}$ & 23 \\
\hline $\mathrm{Et}_{3} \mathrm{PAu}(\mathrm{TATG})^{2}$ & DTNB & 20 \\
\hline $\mathrm{Ph}_{3} \mathrm{PAuSC}_{6} \mathrm{H}_{4} \mathrm{NO}_{2}$ & $\left(\mathrm{SC}_{6} \mathrm{H}_{4} \mathrm{Cl}\right)_{2}$ & 15 \\
\hline $\mathrm{Et}_{3} \mathrm{PAu}(\mathrm{TATG})$ & $\left(\mathrm{SC}_{6} \mathrm{H}_{4} \mathrm{NO}_{2}\right)_{2}$ & 11 \\
\hline $\mathrm{Ph}_{3} \mathrm{PAuSC}_{6} \mathrm{H}_{4} \mathrm{CH}_{3}$ & $\left(\mathrm{SC}_{6} \mathrm{H}_{4} \mathrm{Cl}\right)_{2}$ & 4 \\
\hline $\mathrm{Ph}_{3} \mathrm{PAuSC} \mathrm{H}_{6} \mathrm{Cl}$ & $\left(\mathrm{SC}_{6} \mathrm{H}_{4} \mathrm{Cl}\right)_{2}$ & 3 \\
\hline $\mathrm{Ph}_{3} \mathrm{PAuSC}_{6} \mathrm{H}_{4} \mathrm{NO}_{2}$ & $\left(\mathrm{SC}_{6} \mathrm{H}_{4} \mathrm{CH}_{3}\right)_{2}$ & 3 \\
\hline $\mathrm{Et}_{3} \mathrm{PAu}(\mathrm{TATG})$ & $\left(\mathrm{SC}_{6} \mathrm{H}_{4} \mathrm{Cl}\right)_{2}$ & $<1$ \\
\hline $\mathrm{Et}_{3} \mathrm{PAu}(\mathrm{TATG})$ & $\left(\mathrm{SC}_{6} \mathrm{H}_{4} \mathrm{CH}_{3}\right)_{2}$ & $<1$ \\
\hline $\mathrm{Ph}_{3} \mathrm{PAuSC}_{6} \mathrm{H}_{4} \mathrm{CH}_{3}$ & $\left(\mathrm{SC}_{6} \mathrm{H}_{4} \mathrm{CH}_{3}\right)_{2}$ & 0 \\
\hline $\mathrm{Ph}_{3} \mathrm{PAuSC} \mathrm{H}_{6} \mathrm{H}_{4} \mathrm{Cl}$ & $\left(\mathrm{SC}_{6} \mathrm{H}_{4} \mathrm{CH}_{3}\right)_{2}$ & 0 \\
\hline
\end{tabular}

\subsection{Possible Mechanistic Pathways for Phosphine Oxide Formation in DMSO}

Two possible explanations for formation of phosphine oxide are illustrated in Scheme 1. The first involves dissociation of the phosphine ligand from gold(I), followed by nucleophilic attack on disulfide. The second involves reaction of the intact phosphine gold(I) thiolate complex in which the Au-P bond acts as the nucleophile. Dissociation of phosphine from the gold(I) complex was considered likely because of the well-known reaction of triarylphosphines with disulfides. Mechanistic studies reveal that the reaction of $\mathrm{Ph}_{3} \mathrm{P}$ and disulfide in dioxane/water mixtures is second order and proceeds via nucleophilic attack of $\mathrm{Ph}_{3} \mathrm{P}$ on the $\mathrm{S}-\mathrm{S}$ bond in disulfide, resulting in a thiophosphonium cationic intermediate $\left(\left[R^{\prime} \mathrm{SP} R_{3}\right]^{+}\right)$, which is subsequently hydrolyzed by water to produce phosphine oxide and thiol $[12,13]$. Disulfides with electron withdrawing groups react faster than those with electron donating groups. We have seen a similar trend for reactions of free $\mathrm{Ph}_{3} \mathrm{P}$ with disulfides in DMSO- $d_{6}$ solution. For example, reactions of $c a .5 \mathrm{mM} \mathrm{Ph}_{3} \mathrm{P}$ and $10 \mathrm{mM}^{*} \mathrm{SSR}^{*}\left(R^{*}=\mathrm{C}_{6} \mathrm{H}_{4} \mathrm{NO}_{2}, \mathrm{C}_{6} \mathrm{H}_{4} \mathrm{Cl}, \mathrm{C}_{6} \mathrm{H}_{4} \mathrm{CH}_{3}\right)$ were monitored by ${ }^{31} \mathrm{P}$ NMR and the relative rates of formation of $\mathrm{Ph}_{3} \mathrm{P}=\mathrm{O}$ are $\mathrm{NO}_{2}>>\mathrm{Cl}>\mathrm{CH}_{3}$.

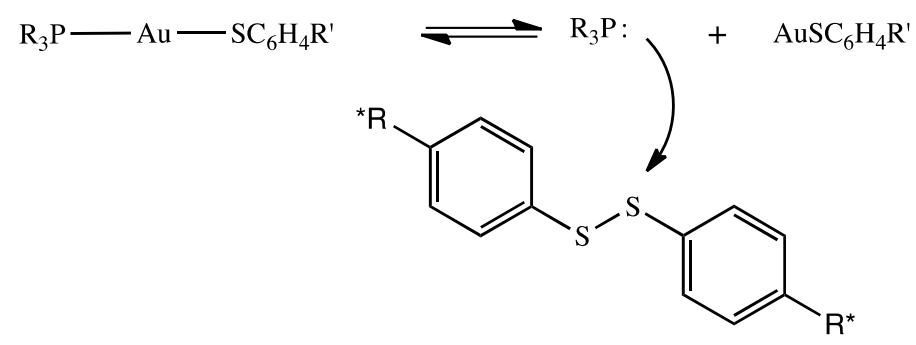

(A)

Scheme 1. Cont. 


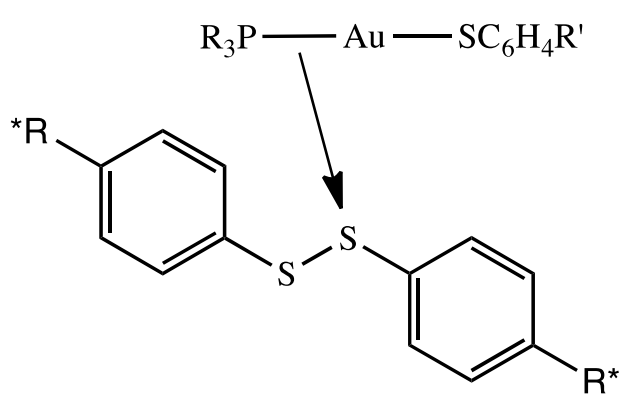

(B)

Scheme 1. (A) Dissociation of phosphine and nucleophilic attack on disulfide; (B) Nucleophilic attack of $\mathrm{Au}-\mathrm{P}$ bond on disulfide.

It is also interesting to note that $\mathrm{Et}_{3} \mathrm{P}=\mathrm{O}$ is known to be an in vivo metabolite of auranofin. Interactions of auranofin with albumin have been studied in vitro. Shaw, et al. proposed that $\mathrm{Et}_{3} \mathrm{P}$, from the $\mathrm{Et}_{3} \mathrm{PAu}(\mathrm{I})$ moiety bound to the cysteine-34 in albumin, is substituted by an additional cysteine thiolate. The released phosphine reacts with a protein disulfide bond, followed by hydrolysis to give $\mathrm{Et}_{3} \mathrm{P}=\mathrm{O}[14,15]$.

\subsection{No Evidence for Dissociation of Phosphine from Phosphine Gold(I) Thiolate in DMSO}

To check for dissociation of phosphine from the phosphine gold(I) thiolate complexes in Table 1, the stability of each gold complex in DMSO- $d_{6}$ was monitored by ${ }^{1} \mathrm{H}$ and ${ }^{31} \mathrm{P}$ NMR. The complexes are stable in this solvent and there is no evidence for dissociation of phosphine over a period of $24 \mathrm{~h}$. An additional check on the stability of the gold-phosphorus bond was performed by adding benzyl azide as a trapping agent [16,17]. In a control reaction, a few drops of neat benzyl azide were added to a $5 \mathrm{mM}$ solution of $\mathrm{PPh}_{3}$ in DMSO- $d_{6}$ and the reaction was observed by ${ }^{31} \mathrm{P}$ NMR. One hour after mixing, all of the phosphine was converted to a mixture of $\mathrm{Ph}_{3} \mathrm{P}=\mathrm{O}$ and $\mathrm{C}_{6} \mathrm{H}_{5} \mathrm{CH}_{2} \mathrm{~N}=\mathrm{PPh}_{3}$. In contrast, when a few drops of neat benzyl azide were added to separate solutions of $\mathrm{Ph}_{3} \mathrm{PAuSC}_{6} \mathrm{H}_{4} \mathrm{CH}_{3}$ and $\mathrm{Ph}_{3} \mathrm{PAuSC}_{6} \mathrm{H}_{4} \mathrm{NO}_{2}$ ( $5 \mathrm{mM}$ in DMSO-d6), the only peak observed in the ${ }^{31} \mathrm{P} \mathrm{NMR}$ was at $c a .39 \mathrm{ppm}$ for the $\mathrm{Ph}_{3} \mathrm{P}$ ligand in $\mathrm{Ph}_{3} \mathrm{PAu}\left(\mathrm{S} R^{\prime}\right)$. These results suggest that the gold(I) complexes are stable in DMSO- $d_{6}$ and phosphine does not dissociate, i.e., the reaction sequence depicted in Scheme 1A is not likely.

\subsection{Water Is the Source of Oxygen for the Formation of $P h_{3} P=O$}

Water is critical to the formation of $R_{3} \mathrm{P}=\mathrm{O}$ in the reaction of free phosphine with disulfide. The next set of experiments were carried out to determine whether water is also critical for the formation of $R_{3} \mathrm{P}=\mathrm{O}$ in the gold(I)/disulfide system. Dimethyl sulfoxide is a hygroscopic solvent and NMR solutions prepared in the atmosphere typically contain water. We therefore prepared a solution of $10 \mathrm{mM} \mathrm{Ph}_{3} \mathrm{PAuSC}_{6} \mathrm{H}_{4} \mathrm{NO}_{2}$ and $10 \mathrm{mM} \mathrm{NO}_{2} \mathrm{C}_{6} \mathrm{H}_{4} \mathrm{SSC}_{6} \mathrm{H}_{4} \mathrm{NO}_{2}$ in DMSO- $d_{6}$ in an argon-filled drybox to minimize the amount of water present. (We used sealed ampoules of $99.5 \%$ DMSO- $d_{6}$ with a water content of $c a$. 60 ppm, or $3.3 \mathrm{mM}$ ). The solution was divided into two portions and a drop of water was added to one of these solutions. Each solution was observed immediately (within $5 \mathrm{~min}$ ) by ${ }^{31} \mathrm{P}$ NMR. In the solution without added water, approximately $35 \%$ of the $\mathrm{Ph}_{3} \mathrm{P}$ had been converted to $\mathrm{Ph}_{3} \mathrm{P}=\mathrm{O}$. Addition of a drop of water (which is an excess) to the second sample caused complete conversion of the phosphine in $\mathrm{Ph}_{3} \mathrm{PAuSC}_{6} \mathrm{H}_{4} \mathrm{NO}_{2}$ to $\mathrm{Ph}_{3} \mathrm{P}=\mathrm{O}$. This demonstrates that water accelerates the formation of phosphine 
oxide in the gold(I)/disulfide system. In addition, GC-MS experiments using labeled water $\left(\mathrm{H}_{2}{ }^{18} \mathrm{O}\right)$ demonstrate the formation of $\mathrm{Ph}_{3} \mathrm{P}={ }^{18} \mathrm{O}$, confirming that water is the source of the oxygen in $\mathrm{Ph}_{3} \mathrm{P}=\mathrm{O}$ (see Experimental Section).

\subsection{What Is the Fate of Gold(I)?}

When a solution of $7.5 \mathrm{mM} \mathrm{Ph}_{3} \mathrm{PAuSC}_{6} \mathrm{H}_{4} \mathrm{CH}_{3}$ and $5.0 \mathrm{mM} \mathrm{NO}_{2} \mathrm{C}_{6} \mathrm{H}_{4} \mathrm{SSC}_{6} \mathrm{H}_{4} \mathrm{NO}_{2}$ in DMSO- $d_{6}$ was monitored by ${ }^{1} \mathrm{H}$ NMR, a new peak at $7.9 \mathrm{ppm}$ (broad doublet) was observed. This peak was assigned to the aromatic protons in $\left[\mathrm{Au}\left(\mathrm{SC}_{6} \mathrm{H}_{4} \mathrm{NO}_{2}\right)_{2}\right]^{-}$on the basis of comparison to a sample prepared independently by reaction of $\mathrm{Au}(\mathrm{tht}) \mathrm{Cl}$ with two equivalents of the sodium salt of para-nitrophenylthiolate $\left(\mathrm{Na}\left[\mathrm{SC}_{6} \mathrm{H}_{4} \mathrm{NO}_{2}\right]\right)$.

\subsection{Mechanistic Reaction Sequence of Disulfide Competition for Phosphine Gold(I) Thiolates}

The competing pathways for formation of thiolate-disulfide exchange and formation of phosphine are summarized in Equations (3)-(7), using as an example the reaction of $\mathrm{Ph}_{3} \mathrm{PAuSC}_{6} \mathrm{H}_{4} \mathrm{CH}_{3}$ and $\left(\mathrm{SC}_{6} \mathrm{H}_{4} \mathrm{NO}_{2}\right)_{2}$.

Thiolate-disulfide exchange:

$$
\mathrm{Ph}_{3} \mathrm{PAuSC}_{6} \mathrm{H}_{4} \mathrm{CH}_{3}+\left(\mathrm{SC}_{6} \mathrm{H}_{4} \mathrm{NO}_{2}\right)_{2} \rightleftarrows \mathrm{Ph}_{3} \mathrm{PAuSC}_{6} \mathrm{H}_{4} \mathrm{NO}_{2}+\mathrm{NO}_{2} \mathrm{C}_{6} \mathrm{H}_{4} \mathrm{SSC}_{6} \mathrm{H}_{4} \mathrm{CH}_{3}
$$

Phosphine oxide formation:

$$
\begin{gathered}
\mathrm{Ph}_{3} \mathrm{PAuSC}_{6} \mathrm{H}_{4} \mathrm{CH}_{3}+\left(\mathrm{SC}_{6} \mathrm{H}_{4} \mathrm{NO}_{2}\right)_{2} \rightleftarrows\left[\mathrm{Ph}_{3} \mathrm{PSC}_{6} \mathrm{H}_{4} \mathrm{NO}_{2}\right]^{+}+\left[\left(\mathrm{NO}_{2} \mathrm{C}_{6} \mathrm{H}_{4} \mathrm{~S}\right) \mathrm{Au}\left(\mathrm{SC}_{6} \mathrm{H}_{4} \mathrm{CH}_{3}\right)\right]^{-} \\
{\left[\mathrm{Ph}_{3} \mathrm{PSC}_{6} \mathrm{H}_{4} \mathrm{NO}_{2}\right]^{+}+\mathrm{H}_{2} \mathrm{O} \rightleftarrows \mathrm{Ph}_{3} \mathrm{PO}+\mathrm{HSC}_{6} \mathrm{H}_{4} \mathrm{NO}_{2}+\mathrm{H}^{+}} \\
\mathrm{HSC}_{6} \mathrm{H}_{4} \mathrm{NO}_{2} \rightleftarrows \mathrm{H}^{+}+\left[\mathrm{SC}_{6} \mathrm{H}_{4} \mathrm{NO}_{2}\right]^{-} \\
{\left[\mathrm{SC}_{6} \mathrm{H}_{4} \mathrm{NO}_{2}\right]^{-}+\left[\left(\mathrm{NO}_{2} \mathrm{C}_{6} \mathrm{H}_{4} \mathrm{~S}\right) \mathrm{Au}\left(\mathrm{SC}_{6} \mathrm{H}_{4} \mathrm{CH}_{3}\right)\right]^{-} \rightleftarrows\left[\mathrm{Au}\left(\mathrm{SC}_{6} \mathrm{H}_{4} \mathrm{NO}_{2}\right)_{2}\right]^{-}+\left[\mathrm{SC}_{6} \mathrm{H}_{4} \mathrm{CH}_{3}\right]^{-}}
\end{gathered}
$$

\subsection{Scheme $1 B$ Is Supported by $2 D\left({ }^{1} H-{ }^{l} H\right)$ NMR Experiments}

The second possibility shown in Scheme 1B is that the Au-P bond acts as nucleophile toward the disulfide. Indirect support for this possibility is provided by $2 \mathrm{D}\left({ }^{1} \mathrm{H}-{ }^{1} \mathrm{H}\right) \mathrm{NMR}$ experiments, described below.

As part of our studies on the mechanism of thiolate-disulfide exchange, we have carried out a series of $2 \mathrm{D}\left({ }^{1} \mathrm{H}-{ }^{1} \mathrm{H}\right)$ NMR ROESY experiments. For the self-exchange reaction between $\left(\mathrm{SC}_{6} \mathrm{H}_{4} \mathrm{NO}_{2}\right)_{2}$ and $\mathrm{Ph}_{3} \mathrm{PAuSC}_{6} \mathrm{H}_{4} \mathrm{NO}_{2}$ in $\mathrm{CD}_{3} \mathrm{CN}$ during a $12 \mathrm{~h}$ ROESY experiment (for which no $\mathrm{R}_{3} \mathrm{PO}$ is detected, vide supra), analysis of the NOE peaks suggests a close approach of the disulfide and the gold(I)-thiolate moiety, which places the disulfide in a position to undergo exchange with the gold(I) bound thiolate [5]. In addition, on the related zinc(II)-thiolate, disulfide exchange reaction, there is experimental data suggesting close association [5,18], as well as DFT calculations which indicate close association of the disulfide with the zinc(II)-thiolate in the transition state [19]. 


\section{8. $2 D\left({ }^{1} \mathrm{H}^{1}{ }^{1} \mathrm{H}\right)$ NMR ROESY Experiments}

2D $\left({ }^{1} \mathrm{H}_{-}{ }^{1} \mathrm{H}\right)$ NMR ROESY experiments were also carried out in DMSO- $d_{6}$. Since formation of phosphine oxide competes with thiolate-disulfide exchange in this solvent, and leads to eventual decomposition of the gold(I) thiolate complex, reactants were chosen to minimize the formation of $\mathrm{R}_{3} \mathrm{PO}$. On the basis of the results shown in Table 1, we reasoned that the more electron donating methyl substituent on the thiolate ligand and the disulfide would produce the least amount of phosphine oxide. However, a nitro substituent on at least one aromatic ring is desirable because these peaks are well separated from the aromatic ring protons in the thiolate and phosphine ligands (i.e., $\mathrm{SC}_{6} \mathrm{H}_{4} \mathrm{CH}_{3}$ and $\mathrm{PPh}_{3}$ ) allowing for easier visualization and assignment of the NOEs. Thus we used $\mathrm{Ph}_{3} \mathrm{PAuSC}_{6} \mathrm{H}_{4} \mathrm{CH}_{3}$ in combination with the unsymmetrical disulfide, $\mathrm{NO}_{2} \mathrm{C}_{6} \mathrm{H}_{4} \mathrm{SSC}_{6} \mathrm{H}_{4} \mathrm{CH}_{3}$. (The unsymmetrical disulfide was prepared in situ by mixing $\mathrm{NO}_{2} \mathrm{C}_{6} \mathrm{H}_{4} \mathrm{SSC}_{6} \mathrm{H}_{4} \mathrm{NO}_{2}$ with an excess of $\mathrm{CH}_{3} \mathrm{C}_{6} \mathrm{H}_{4} \mathrm{SSC}_{6} \mathrm{H}_{4} \mathrm{CH}_{3}$, prior to addition of the gold(I) thiolate complex; see experimental section.)

The 2D $\left({ }^{1} \mathrm{H}-{ }^{1} \mathrm{H}\right)$ NMR ROESY spectrum shown in Figure 2 was acquired over a 4-h period. In this time frame, the starting gold(I) thiolate complex has undergone thiolate-disulfide exchange according to Equation (8). This is evident from the peaks labeled $\mathrm{H}_{3}$ and $\mathrm{H}_{4}$, which belong to the thiolate aromatic ring in $\mathrm{Ph}_{3} \mathrm{PAuSC}_{6} \mathrm{H}_{4} \mathrm{NO}_{2}$, and $\mathrm{H}_{1}$ and $\mathrm{H}_{2}$ for the nitro aromatic ring in $\mathrm{NO}_{2} \mathrm{C}_{6} \mathrm{H}_{4} \mathrm{SSC}_{6} \mathrm{H}_{4} \mathrm{CH}_{3}$ (see Scheme 2 for labels).

$\mathrm{Ph}_{3} \mathrm{PAuSC}_{6} \mathrm{H}_{4} \mathrm{CH}_{3}+\mathrm{NO}_{2} \mathrm{C}_{6} \mathrm{H}_{4} \mathrm{SSC}_{6} \mathrm{H}_{4} \mathrm{CH}_{3} \rightleftarrows \mathrm{Ph}_{3} \mathrm{PAuSC}_{6} \mathrm{H}_{4} \mathrm{NO}_{2}+\mathrm{CH}_{3} \mathrm{C}_{6} \mathrm{H}_{4} \mathrm{SSC}_{6} \mathrm{H}_{4} \mathrm{CH}_{3}$

The remaining peaks in the $1 \mathrm{D}{ }^{1} \mathrm{H}-\mathrm{NMR}$ spectra are assigned as follows, starting at the high field side. The intense doublets at 7.38 and $7.18 \mathrm{ppm}$ are due to the large excess of $\mathrm{CH}_{3} \mathrm{C}_{6} \mathrm{H}_{4} \mathrm{SSC}_{6} \mathrm{H}_{4} \mathrm{CH}_{3}$. The doublets at 7.42 and 7.2ppm (partially hidden by the symmetrical disulfide peak at $7.18 \mathrm{ppm}$ ) are assigned to the methyl aromatic ring in $\mathrm{NO}_{2} \mathrm{C}_{6} \mathrm{H}_{4} \mathrm{SSC}_{6} \mathrm{H}_{4} \mathrm{CH}_{3}$. The complex multiplet at $7.6 \mathrm{ppm}$ is assigned to $\mathrm{PPh}_{3}$ and a small amount of $\mathrm{Ph}_{3} \mathrm{PO}$. (The ${ }^{31} \mathrm{P}$ NMR spectrum collected at the end of the $2 \mathrm{D}$ $\left({ }^{1} \mathrm{H}-{ }^{1} \mathrm{H}\right)$ experiment, shows $\mathrm{ca} .3 \% \mathrm{Ph}_{3} \mathrm{P}=\mathrm{O}$ formation, which indicates that the conditions minimize the formation of phosphine oxide.)

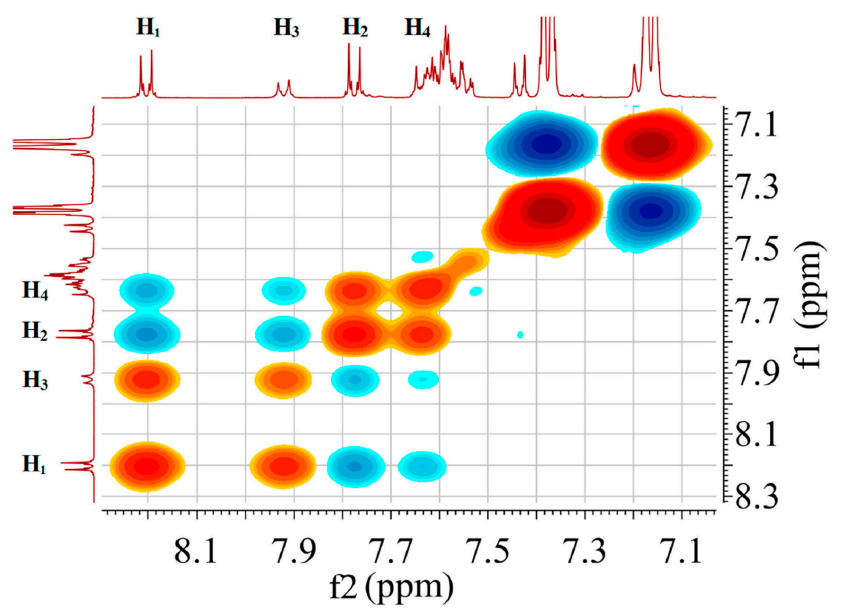

Figure 2. 2D $\left({ }^{1} \mathrm{H}-{ }^{1} \mathrm{H}\right)$ ROESY spectrum in the aromatic region showing interaction between $\mathrm{Ph}_{3} \mathrm{PAuSC}_{6} \mathrm{H}_{4} \mathrm{NO}_{2}$ and $\mathrm{CH}_{3} \mathrm{C}_{6} \mathrm{H}_{4} \mathrm{SSC}_{6} \mathrm{H}_{4} \mathrm{NO}_{2}$ (DMSO-d6). See Scheme 2 for assignment of aromatic protons labeled $\mathrm{H}_{1}, \mathrm{H}_{2}, \mathrm{H}_{3}$, and $\mathrm{H}_{4}$. (The intense peaks at 7.16 and 7.37 ppm are due to the excess $\mathrm{CH}_{3} \mathrm{C}_{6} \mathrm{H}_{4} \mathrm{~S}-\mathrm{SC}_{6} \mathrm{H}_{4} \mathrm{CH}_{3}$; see Experimental Section.) 

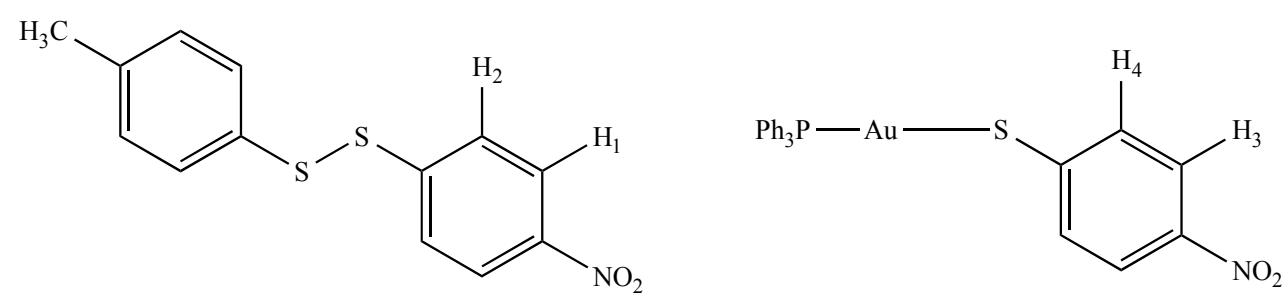

Scheme 2. Labels for aromatic ring protons in the disulfide and gold(I) thiolate complex.

The off diagonal contours in the 2D $\left({ }^{1} \mathrm{H}-{ }^{1} \mathrm{H}\right)$ ROESY spectrum provide important conformational information. Cross peaks with the same phasing as along the diagonal (red), indicate molecular exchange while the oppositely phased contours (blue) indicate long-range spatial interactions. The red, cross peaks centered at 7.9 and $8.2 \mathrm{ppm}$ indicate thiolate-disulfide exchange between $\mathrm{H}_{3}$ on the thiolate in $\mathrm{Ph}_{3} \mathrm{PAuSC}_{6} \mathrm{H}_{4} \mathrm{NO}_{2}$ and $\mathrm{H}_{1}$ on the nitro end of the unsymmetrical disulfide, $\mathrm{NO}_{2} \mathrm{C}_{6} \mathrm{H}_{4} \mathrm{SSC}_{6} \mathrm{H}_{4} \mathrm{CH}_{3}$. (This is a nonproductive exchange since no new molecules are formed.) Intramolecular, long-range interactions between protons on the same ring (ortho to each other) are indicated by blue cross peaks for $\mathrm{H}_{1}$ and $\mathrm{H}_{2}$ in the disulfide, and also for $\mathrm{H}_{3}$ and $\mathrm{H}_{4}$ on the thiolate.

The most interesting aspect of the $2 \mathrm{D}\left({ }^{1} \mathrm{H}-{ }^{1} \mathrm{H}\right)$ ROESY spectrum is the set of blue cross peaks, which indicate intermolecular long-range interactions between $\mathrm{H}_{4}$ on the thiolate ligand and $\mathrm{H}_{1}$ on the unsymmetrical disulfide as well as $\mathrm{H}_{3}$ on thiolate and $\mathrm{H}_{2}$ on disulfide. The distance between spatially close nuclei can be estimated according to the Equation (9) [20], where $\eta_{\mathrm{ab}}$ is the ROE cross-peak volume (intensity) and $r_{\mathrm{ab}}$ is the inter-proton distance of the two protons " $\mathrm{a}$ " and " $\mathrm{b}$ ". The term, $r_{\text {ref }}$ is a known distance between two protons and its ROE volume is given by $\eta_{\mathrm{ref}}[20]$.

$$
\frac{r_{\mathrm{ab}}}{r_{\mathrm{ref}}}=\left(\frac{\eta_{\mathrm{ref}}}{\eta_{\mathrm{ab}}}\right)^{1 / 6}
$$

For our calculation, $r_{\text {ref }}$ was chosen as the intramolecular distances between $\mathrm{H}_{1}$ and $\mathrm{H}_{2}$ in the disulfide. The crystal structure of the symmetrical disulfide, $\left(\mathrm{SC}_{6} \mathrm{H}_{4} \mathrm{NO}_{2}\right)_{2}$, is available in the Cambridge Structural Database (CSD Refcode: NIPHSS) [21,22] and the average distance between these protons is $2.365 \AA$. Using this value and the experimental ROE volumes, the spatial separation between $\mathrm{H}_{1} \ldots \mathrm{H}_{4}$, and $\mathrm{H}_{2} \ldots \mathrm{H}_{3}$ is estimated to be $2.6 \AA$.

\subsection{Visualizing the Association of Disulfide and the Phosphine Gold(I) Thiolate Complex}

Figure 3 shows two views of a cartoon drawing to help visualize the association (and exchange) between disulfide and the phosphine gold(I) thiolate complex. The figure was constructed in Autodesk using typical bond lengths and angles for the disulfide and the gold(I) complex (e.g., the S-S, Au-S, and $\mathrm{Au}-\mathrm{P}$ bonds are 2.02, 2.30, and $2.26 \AA$, respectively) [21,23]. The spatial orientations of the two molecules were adjusted to achieve intermolecular $\mathrm{H}_{1} \ldots \mathrm{H}_{4}$, and $\mathrm{H}_{2} \ldots \mathrm{H}_{3}$ distances of $2.6 \AA$, the distance estimated by analysis of the ROESY data. The $\mathrm{S}-\mathrm{S}$ bond is oriented approximately parallel to the Au-S bond and the intermolecular S...S, S...Au and S...P distances are 3.66, 3.60, and $4.44 \AA$, respectively. We emphasize that this cartoon is not the result of a calculation but is useful to envision a possible conformational arrangement of the disulfide and gold(I) thiolate complex that is consistent with the ROESY data. 


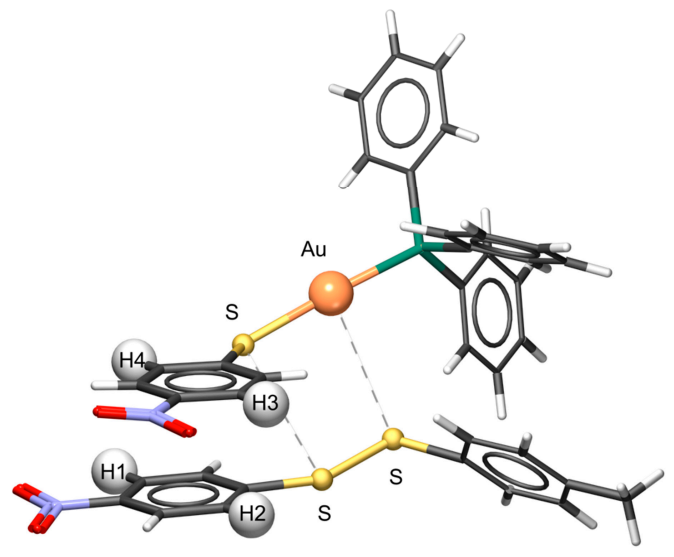

(A)

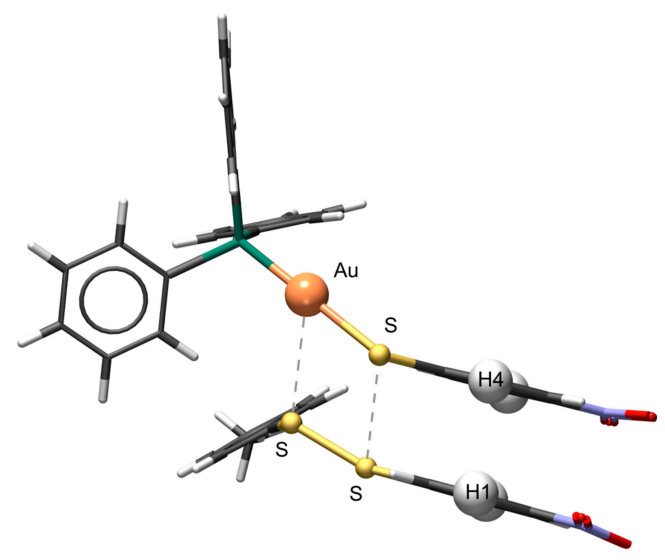

(B)

Figure 3. Cartoon drawings in two different views ( $\mathbf{A}$ and $\mathbf{B}$ ) to illustrate a possible orientation of $\mathrm{Ph}_{3} \mathrm{PAu}\left(\mathrm{SC}_{6} \mathrm{H}_{4} \mathrm{NO}_{2}\right)$ and the unsymmetrical disulfide, $\mathrm{CH}_{3} \mathrm{C}_{6} \mathrm{H}_{4} \mathrm{SSC}_{6} \mathrm{H}_{4} \mathrm{NO}_{2}$. The distance between the aromatic protons, $\mathrm{H}_{1}$ and $\mathrm{H}_{4}$, and $\mathrm{H}_{2}$ and $\mathrm{H}_{3}$ was set at $2.60 \AA$. The S...S and Au...S distances are 3.66 and $3.60 \AA$, respectively. The drawings were generated by using Autodesk 3DS MAX 2013.

Figure 3 also is useful for visualizing the competing reaction that leads to phosphine oxide. Sliding the disulfide along the linear $\mathrm{S}-\mathrm{Au}-\mathrm{P}$ moiety toward the $\mathrm{Au}-\mathrm{P}$ bond would appear to require a relatively small spatial reorganization and would set up the disulfide to react across the $\mathrm{Au}-\mathrm{P}$ bond rather than the $\mathrm{Au}-\mathrm{S}$ bond (see Scheme 3). Reaction of gold(I) with the more electron withdrawing half of the unsymmetrical disulfide is consistent with the known chemistry of gold(I) [24]. The reaction is promoted by DMSO, a solvent with a high dielectric constant $(\varepsilon=46.6)$, which may help to stabilize the charged species that form following scission of the S-S bond.

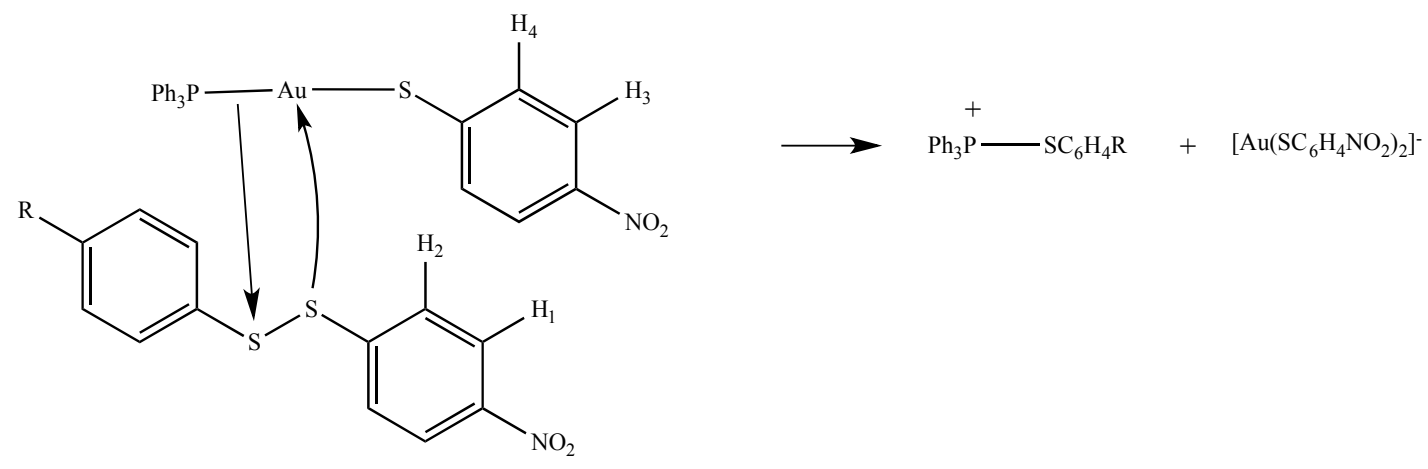

Scheme 3. Competing reaction that leads to phosphine oxide.

\section{Experimental Section}

\subsection{Chemicals and Instrumentation}

All NMR solvents were purchased from Cambridge Isotope Laboratories, Inc. (Tewksbury, MA, USA) Only for $2 \mathrm{D}\left({ }^{1} \mathrm{H}-{ }^{1} \mathrm{H}\right) \mathrm{NMR}$, solvents in ampules were used as received and solvents in the bottles were used after degassing by 5-10 freeze-pump cycles. Triphenylphosphine oxide ( $\left.\mathrm{Ph}_{3} \mathrm{PO}\right)$, triethylphosphine oxide (Et3 $\mathrm{PO})$, triphenylphosphine $\left(\mathrm{PPh}_{3}\right)$, benzyl azide $\left(\mathrm{BzN}_{3}\right)$, bis(4-chlorophenyl) 
disulfide $\left[\left(\mathrm{ClC}_{6} \mathrm{H}_{4} \mathrm{~S}\right)_{2}\right]$, water $\left(\mathrm{H}_{2}{ }^{18} \mathrm{O}\right)$ and Ellman's reagent [5,5'-dithiobis-(2-nitrobenzoic acid) or DTNB] were purchased from Sigma-Aldrich (St. Louis, MO, USA) and used as received. Bis(4-nitrophenyl) disulfide $\left[\left(\mathrm{O}_{2} \mathrm{NC}_{6} \mathrm{H}_{4} \mathrm{~S}\right)_{2}\right]$ and bis(4-methylphenyl) disulfide $\left[\left(\mathrm{CH}_{3} \mathrm{C}_{6} \mathrm{H}_{4} \mathrm{~S}\right)_{2}\right]$ were purchased from Sigma-Aldrich (St. Louis, MO, USA) and used after recrystallization. Auranofin [(Et 3 P)Au(TATG); TATG = 2,3,4,6-tetraacetyl-1-thio-D-glucopyranosato] was purchased from Enzo Life Sciences (Farmingdale, NY, USA). Syntheses of Au(tht)Cl [25], and phosphine gold(I) thiolates [23], were carried out according to previously reported procedures. Experiments were carried out under atmospheric conditions unless otherwise stated.

${ }^{31} \mathrm{P}\left\{{ }^{1} \mathrm{H}\right\}$ NMR spectra were obtained at $26{ }^{\circ} \mathrm{C}$ in deuterated solvents on a Varian (Palo Alto, CA, USA) UNITYplus-400 MHz "Oxford" NMR spectrometer operating at $161.9 \mathrm{MHz} .{ }^{31} \mathrm{P}\left\{{ }^{1} \mathrm{H}\right\} \mathrm{NMR}$ spectra were referenced to $85 \% \mathrm{H}_{3} \mathrm{PO}_{4}$ (external standard).

The sample tubes for $2 \mathrm{D}\left({ }^{1} \mathrm{H}-{ }^{1} \mathrm{H}\right)$ ROESY (rotating frame Overhauser enhancement spectroscopy) NMR experiments were prepared in a Vacuum Atmospheres dry box under an argon environment and were capped with an air-tight seal. Two-dimensional NMR spectra were acquired at a constant temperature $\left(30^{\circ} \mathrm{C}\right)$ on a Varian (Palo Alto, CA, USA) UNITYplus-400 MHz "Oxford" NMR spectrometer (399.96 MHz for ${ }^{1} \mathrm{H}$ ) equipped with 4-nuc probes. Chemical shifts were referenced to residual ${ }^{1} \mathrm{H}$ signals of the deuterated solvents.

GC-MS analyses were performed using a Thermo Scientific Trace (Waltham, MA, USA) GC Ultra gas chromatograph and Thermo Scientific (Waltham, MA, USA) ISQ mass spectrometer. Compound separation was achieved with a Rtx5-MS column (30 $\mathrm{m} \times 0.25 \mathrm{~mm}$ i.d., crossbond 5\% diphenyl/95\% dimethyl polysiloxane $\times 0.25 \mu \mathrm{m}$ (df) capacity Film thickness, Restek Corp., Bellefonte, PA, USA). The column flow rate was $2 \mathrm{~mL} / \mathrm{min}$. The oven temperature was held at $50{ }^{\circ} \mathrm{C}$ for $1 \mathrm{~min}$, then increased to $350{ }^{\circ} \mathrm{C}$ (at a rate of $20^{\circ} \mathrm{C} / \mathrm{min}$ ) and held at that temperature for $1 \mathrm{~min}$. Injection, MS transfer line, and ion source temperatures were 270,250 , and $200^{\circ} \mathrm{C}$, respectively. Electron ionization mass spectrometric data from $\mathrm{m} / \mathrm{z} 50$ to $300 \mathrm{amu}$ were collected using an ionization voltage of $70 \mathrm{eV}$. Compound identifications were made by comparing mass spectral patterns with those from known samples and the use of NIST mass spectra database.

\subsection{Calibration of ${ }^{31} \mathrm{P}$ NMR Integrals for a Mixture of $\mathrm{Ph}_{3} \mathrm{PAuSC} \mathrm{CH}_{4} \mathrm{CH}_{3}$ and $\mathrm{Ph}_{3} \mathrm{PO}$}

The amount of $0.5 \mathrm{~mL}$ of a $9.96 \mathrm{mM}$ solution of $\mathrm{Ph}_{3} \mathrm{PAuSC}_{6} \mathrm{H}_{4} \mathrm{CH}_{3}$ in DMSO- $d_{6}$ was mixed in a vial with $0.5 \mathrm{~mL}$ of a $10.42 \mathrm{mM}$ solution of $\mathrm{Ph}_{3} \mathrm{PO}$ in $\mathrm{DMSO}-d_{6}$. The resulting solution mixture containing $4.98 \mathrm{mM}$ of $\mathrm{Ph}_{3} \mathrm{PAuSC}_{6} \mathrm{H}_{4} \mathrm{CH}_{3}$ and $5.21 \mathrm{mM} \mathrm{Ph}_{3} \mathrm{PO}$ was transferred into a NMR tube and investigated by ${ }^{31} \mathrm{P}\left\{{ }^{1} \mathrm{H}\right\} \mathrm{NMR}$ experiments. The integral ratio for the peak at $39.2 \mathrm{ppm}(\mathrm{Au}-\mathrm{P})$ to the peak at 26.5 $(\mathrm{P}=\mathrm{O})$ was $c a$. 1:1.

\subsection{Procedure for Measuring \% of Phosphine Oxide}

The amount of $0.4 \mathrm{~mL}$ of a $20.0 \mathrm{mM}$ solution of $\mathrm{Ph}_{3} \mathrm{PAuSC}_{6} \mathrm{H}_{4} R\left(R=\mathrm{CH}_{3}, \mathrm{Cl}_{1}, \mathrm{NO}_{2}\right)$ or Et 3 PAu(TATG $)$ in DMSO- $d_{6}$ was mixed in a vial with $0.4 \mathrm{~mL}$ of a $20.0 \mathrm{mM}$ solution of $\left(R^{\prime} \mathrm{C}_{6} \mathrm{H}_{4} \mathrm{~S}\right)_{2}\left(R^{\prime}=\mathrm{CH}_{3}, \mathrm{Cl}_{2} \mathrm{NO}_{2}\right)$ or DTNB in DMSO- $d_{6}$. The solution mixture containing $10.0 \mathrm{mM} \mathrm{Ph}_{3} \mathrm{PAuSC}_{6} \mathrm{H}_{4} \mathrm{R}$ and $10.0 \mathrm{mM}$ $\left(R^{\prime} \mathrm{C}_{6} \mathrm{H}_{4} \mathrm{~S}\right)_{2}$ or DTNB was transferred into a NMR tube and investigated by ${ }^{31} \mathrm{P}\left\{{ }^{1} \mathrm{H}\right\}$ NMR array experiments. The same experimental procedure was carried out for the reaction between 
$\mathrm{Et}_{3} \mathrm{PAuSC} \mathrm{C}_{4} \mathrm{HO}_{2}$ and $\left(\mathrm{O}_{2} \mathrm{NC}_{6} \mathrm{H}_{4} \mathrm{~S}\right)_{2}$ in $\mathrm{DMSO}-d_{6}$. The $\mathrm{Au}-\mathrm{P} R_{3}$ peak and $R_{3} \mathrm{P}=\mathrm{O}$ peaks were integrated and the $\% \mathrm{R}_{3} \mathrm{PO}$ is based on the ratio of the $\mathrm{R}_{3} \mathrm{P}=\mathrm{O}$ integral to the total phosphorus signal.

\subsection{Test for Free Phosphine; Reaction of PPh3 and $\mathrm{N}_{3} \mathrm{Bz}$ in DMSO-d6}

Four drops of benzyl azide $\left(\mathrm{N}_{3} \mathrm{Bz}\right)(\sim 1.5 \mathrm{mmol})$ were added into $0.75 \mathrm{~mL}$ of a $5 \mathrm{mM}$ solution of $\mathrm{Ph}_{3} \mathrm{PAuSC}{ }_{6} \mathrm{H}_{4} \mathrm{CH}_{3}$ in DMSO- $d_{6} .{ }^{31} \mathrm{P}\left\{{ }^{1} \mathrm{H}\right\}$ NMR spectra were observed over the time. The same reaction was carried out for $\mathrm{Ph}_{3} \mathrm{PAuSC}_{6} \mathrm{H}_{4} \mathrm{NO}_{2}$ in DMSO- $d_{6}$. As a control, four drops of benzyl azide $\left(\mathrm{N}_{3} \mathrm{Bz}\right)$ $(\sim 1.5 \mathrm{mmol})$ were added into $0.75 \mathrm{~mL}$ of $5 \mathrm{mM}$ solution of $\mathrm{PPh}_{3}$ in DMSO- $d_{6}$. The ${ }^{31} \mathrm{P}\left\{{ }^{1} \mathrm{H}\right\}$ NMR spectra were observed over the time.

\subsection{Test for Influence of Water}

Solutions of $\mathrm{Ph}_{3} \mathrm{PAuSC}_{6} \mathrm{H}_{4} \mathrm{NO}_{2}(20 \mathrm{mM})$ and $\left(\mathrm{SC}_{6} \mathrm{H}_{4} \mathrm{NO}_{2}\right)_{2}(20 \mathrm{mM})$ in DMSO- $d_{6}$ were prepared in an argon-filled drybox. Equal volumes of solutions were mixed and the mixture was divided into two NMR tubes. The ${ }^{31} \mathrm{P}\left\{{ }^{1} \mathrm{H}\right\}$ NMR spectrum was obtained for one sample while keeping the second sample in the drybox. A drop of water was added to the second sample and the ${ }^{31} \mathrm{P}\left\{{ }^{1} \mathrm{H}\right\}$ NMR spectrum was obtained.

\subsection{GC-MS Experiment for Source of Water}

The amount of $0.2 \mathrm{~mL}$ of $\mathrm{H}_{2}{ }^{18} \mathrm{O}$ was transferred into $2 \mathrm{~mL}$ of DMSO- $d_{6}$, which contained $90 \mathrm{ppm}$ $(5 \mathrm{mM})$ water as received from the manufacturer. This solution was used to prepare solutions in the drybox for ${ }^{31} \mathrm{P}\left\{{ }^{1} \mathrm{H}\right\}$ NMR and GC-MS analysis as follows.

A solution of $\mathrm{Ph}_{3} \mathrm{PAuSC}_{6} \mathrm{H}_{4} \mathrm{CH}_{3}(5.8 \mathrm{mg}$ in $1.1 \mathrm{~mL}, 10.0 \mathrm{mM})$ in DMSO- $d_{6}$ was mixed in a vial with a solution of $\left(\mathrm{O}_{2} \mathrm{NC}_{6} \mathrm{H}_{4} \mathrm{~S}\right)_{2}(3.1 \mathrm{mg}$ in $1.1 \mathrm{~mL}, 10.0 \mathrm{mM})$ in DMSO- $d_{6}$. Then $0.75 \mathrm{~mL}$ of the solution mixture was transferred into an NMR tube and investigated by ${ }^{31} \mathrm{P}$ NMR. A separate sample $(1 \mathrm{~mL})$ of the same solution was transferred into a vial for GC-MS analysis.

A solution of $\mathrm{Ph}_{3} \mathrm{PO}$ in DMSO- $d_{6}(1.3 \mathrm{mg}$ in $1.0 \mathrm{~mL}, 4.7 \mathrm{mM})$ was prepared and analyzed by GC-MS as a reference.

\subsection{Reaction of $\mathrm{Au}(\mathrm{tht}) \mathrm{Cl}$ and $\mathrm{Na}\left[\mathrm{SC}_{6} \mathrm{H}_{4} \mathrm{NO}_{2}\right]$}

The reaction was carried out under $\mathrm{N}_{2}$ using using Schlenk techniques. A solution of sodium methoxide $(0.09 \mathrm{~g}, 1.56 \mathrm{mmol})$ in $\mathrm{CH}_{3} \mathrm{OH}(10 \mathrm{~mL})$ was transferred via cannula into a solution of 4-nitrobenzenethiol $(0.24 \mathrm{~g}, 1.56 \mathrm{mmol})$ in $\mathrm{CH}_{2} \mathrm{Cl}_{2}(20 \mathrm{~mL})$. After stirring at $0{ }^{\circ} \mathrm{C}$ for five min., the mixture was transferred into a solution of $\mathrm{Au}(\mathrm{tht}) \mathrm{Cl}(0.25 \mathrm{~g}, 0.78 \mathrm{mmol})$ in $\mathrm{CH}_{2} \mathrm{Cl}_{2}(20 \mathrm{~mL})$. The final mixture was stirred for 30 mins at $0{ }^{\circ} \mathrm{C}$. The product was obtained by reducing the solvent in vacuo and then filtering through a sintered glass crucible in air. The product was washed thoroughly with EtOH and dried under a stream of $\mathrm{N}_{2}$. Yield calculated for $\mathrm{Na}\left[\mathrm{Au}\left(\mathrm{SC}_{6} \mathrm{H}_{4} \mathrm{NO}_{2}\right)_{2}\right]$ : $0.36 \mathrm{~g}, 90.12 \%$. The sample was dissolved in DMSO- $d_{6}$ to obtain a ${ }^{1} \mathrm{H}$ NMR spectrum. There are two sets of doublets; the set with lower intensity centered at 7.89 and $7.60 \mathrm{ppm}$ appears to convert to a more intense set centered at 7.87 and $7.55 \mathrm{ppm}$. Over time, the more intense set decreases and no new peaks grow in as a pale yellow solid 
precipitates, which is likely a gold(I) thiolate polymer since it is only sparingly soluble in DMSO and insoluble in other solvents.

\section{8. $2 \mathrm{D}\left({ }^{1} \mathrm{H}^{-}{ }^{1} \mathrm{H}\right) \mathrm{ROESY}$ Experiment}

All solutions were prepared in an argon-filled drybox. Preparation of unsymmetrical disulfide: the two symmetrical disulfides, $\left(\mathrm{SC}_{6} \mathrm{H}_{4} \mathrm{NO}_{2}\right)_{2}$ and $\left(\mathrm{SC}_{6} \mathrm{H}_{4} \mathrm{CH}_{3}\right)_{2}$ were combined in an $\sim 1: 4$ ratio and dissolved in $1 \mathrm{~mL}$ of DMSO- $d 6$. (Complete conversion of $\left(\mathrm{SC}_{6} \mathrm{H}_{4} \mathrm{NO}_{2}\right)_{2}$ to $\mathrm{CH}_{3} \mathrm{C}_{6} \mathrm{H}_{4} \mathrm{SSC}_{6} \mathrm{H}_{4} \mathrm{NO}_{2}$ under these conditions was confirmed by ${ }^{1} \mathrm{H}$ NMR in a separate experiment.) After $30 \mathrm{~min}$, the disulfide mixture was transferred into a vial containing $\mathrm{Ph}_{3} \mathrm{PAu}\left(\mathrm{SC}_{6} \mathrm{H}_{4} \mathrm{CH}_{3}\right)$. All solids were completely dissolved. The final concentrations of $\mathrm{Ph}_{3} \mathrm{PAu}\left(\mathrm{SC}_{6} \mathrm{H}_{4} \mathrm{NO}_{2}\right), \mathrm{CH}_{3} \mathrm{C}_{6} \mathrm{H}_{4} \mathrm{SSC}_{6} \mathrm{H}_{4} \mathrm{NO}_{2}$, and $\left(\mathrm{SC}_{6} \mathrm{H}_{4} \mathrm{CH}_{3}\right)_{2}$ at the end of the 2D experiment ( $\sim 3 \mathrm{~h})$ were estimated by integration to be 20,30 and $160 \mathrm{mM}$, respectively. The reaction mixture was transferred into a screw cap NMR tube and a ROESY experiment was carried out with the $\pi / 2-t 1-\pi / 2-t_{\mathrm{m}}$ (spin lock) $-\pi / 2$-FID pulse sequence by setting the previously measured PW90 and $\mathrm{T}_{1}$ for a dummy sample in DMSO- $d_{6}$. An $8 \mathrm{~s}$ mixing time was applied. The spectra were recorded with 128 increments in $t 1$ values and 512 data points for the $t 2$ dimension with 4 scans per $t 1$ increment with a relaxation delay of $3 \mathrm{~s} .2 \mathrm{D}\left({ }^{1} \mathrm{H}-{ }^{1} \mathrm{H}\right)$ NMR data were processed with MestReNova NMR software (8.1.1, MestRelab Research, Santiago de Compostela, Spain, 2013).

The cartoon drawing showing a possible orientation of the disulfide and phosphine gold(I) thiolate, which is consistent with the $2 \mathrm{D}\left({ }^{1} \mathrm{H}-{ }^{1} \mathrm{H}\right)$ ROESY experimental results was constructed in Autodesk $3 \mathrm{ds}$ MAX (2013, Autodesk, San Rafael, CA, USA).

\section{Conclusions}

The formation of phosphine oxide in the phosphine gold(I) thiolate-disulfide system shares some features with the reaction of free phosphine and disulfide; i.e., disulfides with electron withdrawing substituents react faster, and water is the source of oxygen. The presence of water is necessary but not sufficient in the gold(I)thiolate-disulfide system since phosphine oxide was not observed in acetonitrile, which also contains $\mathrm{mM}$ concentrations of water. There is no evidence for dissociation of the phosphine ligand from the gold(I) complex prior to reaction with disulfide. This suggests that the Au-P bond acts as a nucleophile to attack the $\mathrm{S}-\mathrm{S}$ bond. $2 \mathrm{D}\left({ }^{1} \mathrm{H}-{ }^{1} \mathrm{H}\right)$ NMR ROESY experiments provide evidence for a close association between disulfide and the gold(I) complex, which we have interpreted as a possible intermediate in the thiolate-disulfide exchange reaction. In addition, we suggest that a small spatial reorganization would allow the disulfide to react with the $\mathrm{Au}-\mathrm{P}$ bond. The two disulfides which produce the most phosphine oxide are $\left(\mathrm{SC}_{6} \mathrm{H}_{4} \mathrm{NO}_{2}\right)_{2}$ and DTNB. The corresponding thiols of these disulfides have low pKa's (5.5 and 2.95, respectively) $[12,26]$ and the thiolates would be expected to have a strong affinity for gold(I) [24]. This may be an important factor for the formation of the bis-thiolate gold(I) anion shown in Scheme 3. However, the relative affinity of thiolates for gold(I) would also be expected to drive the thiolate-disulfide exchange reaction. Thus the factors controlling the competition between thiolate-disulfide exchange and phosphine oxide formation are subtle and need to be more thoroughly investigated. Finally we have established that phosphine oxide formation happens on a longer time scale than thiolate-disulfide exchange, which is important for kinetic studies aimed at understanding the latter reaction. 


\section{Acknowledgments}

The authors wish to thank Brian Frederick for his assistance with GC-MS experiments.

\section{Author Contributions}

The syntheses, ${ }^{1} \mathrm{H},{ }^{31} \mathrm{P}$ and $2 \mathrm{D}$ NMR experiments were performed by Gamage S. P. Garusinghe. Mostapha Aghamoosa contributed to experiments involving auranofin. Meaghan McKinnon carried reactions of free triphenylphosphine and disulfide. S. Max Bessey constructed Figure 3 and contributed to discussions of the association of disulfide and the phosphine gold(I) thiolate complex. Mitchell R. M. Bruce and Alice E. Bruce supervised the research. Gamage S. P. Garusinghe, Mitchell R. M. Bruce and Alice E. Bruce are responsible for the discussion, analysis of data and writing of the manuscript.

\section{Conflicts of Interest}

The authors declare no conflict of interest.

\section{References}

1. Whitesides, G.M.; Lilburn, J.E.; Szajewski, R.P. Rates of thiol-disulfide interchange reactions between mono- and dithiols and Ellman's reagent. J. Org. Chem. 1977, 42, 332-338.

2. Fernandes, P.A.; Ramos, M.J. Theoretical insights into the mechanism for thiol/disulfide exchange. Chemistry 2004, 10, 257-266.

3. DiLorenzo, M.; Ganesh, S.; Tadayon, L.; Chen, J.; Bruce, M.R.M.; Bruce, A.E. Reactions of organic disulfides and gold(I) complexes. Met.-Based Drugs 1999, 6, 247-253.

4. Mohamed, A.A.; Abdou, H.E.; Chen, J.; Bruce, A.E.; Bruce, M.R.M. Perspectives in Inorganic and Bioinorganic Gold Sulfur Chemistry. Comments Inorg. Chem. 2002, 23, 321-334.

5. Garusinghe, G.S.P. Kinetic Analysis of Metal Assisted-Thiolate Disulfide Exchange $(M=\mathrm{Au}, \mathrm{Zn})$. Ph.D. Thesis, The University of Maine, Orono, ME, USA, May 2013.

6. Bachman, R.E.; Bodolosky-Bettis, S.A.; Pyle, C.J.; Gray, M.A. Reversible Oxidative Addition and Reductive Elimination of Fluorinated Disulfides at Gold(I) Thiolate Complexes: A New Ligand Exchange Mechanism. J. Am. Chem. Soc. 2008, 130, 14303-14310.

7. Garusinghe, G.S.P.; Bessey, S.M.; Bruce, A.E.; Bruce, M.R.M. Interactions between Metal Thiolate, $R_{3} \mathrm{PAuSC}_{6} \mathrm{H}_{4} \mathrm{NO}_{2}(R=\mathrm{Ph}$ and $\mathrm{Et})$ and Bis(4-nitrophenyl) Disulfide. In Proceedings of the 36th Northeast Regional Meeting of the American Chemical Society, Hartford, CT, USA, 7-10 October 2009.

8. Chandrasoma, A.; Bruce, A.; Bruce, M. Insight into Metal-Mediated Thiol-Disulfide Exchange. In Proceedings of the 37th Northeast Regional Meeting of the American Chemical Society, Burlington, VT, USA, 29 June-2 July 2008.

9. Aghamoosa, M.; Briggs, B.; Harriman, E.; Cashman, A.; Bruce, A.; Bruce, M. Gold(I)-Mediated Disulfide Exchange Kinetics as a Function of Solvent Dielectric Constant. In Proceedings of the 37th Northeast Regional Meeting of the American Chemical Society, Burlington, VT, USA, 29 June-2 July 2008. 
10. DiLorenzo, M.A.; Ganesh, S.; Bruce, A.E.; Bruce, M.R.M. Gold(I) mediated thiolate/disulfide exchange reactions. In Proceedings of the 213th ACS National Meeting, San Francisco, CA, USA, 13-17 April 1997.

11. Garusinghe, G.S.P.; Bessey, S.M.; Boyd, C.; Aghamoosa, M.; Frederick, B.; Bruce, M.R.M.; Bruce, A.E. (University of Maine, Orono, ME, USA). Determination of dimethyl sulfide in dimethyl sulfoxide. Unpublished work, 2015.

12. Overman, L.E.; Matzinge, D.; Oconnor, E.M.; Overman, J.D. Nucleophilic Cleavage of Sulfur-Sulfur Bond by Phosphorus Nucleophiles-Kinetic Study of Reduction of Aryl Disulfides with Triphenylphosphine and Water. J. Am. Chem. Soc. 1974, 96, 6081-6089.

13. Dmitrenko, O.; Thorpe, C.; Bach, R.D. Mechanism of SN2 Disulfide Bond Cleavage by Phosphorus Nucleophiles. Implications for Biochemical Disulfide Reducing Agents. J. Org. Chem. 2007, 72, 8298-8307.

14. Shaw, C.F.; Isab, A.A.; Hoeschele, J.D.; Starich, M.; Locke, J.; Schulteis, P.; Xiao, J. Oxidation of the phosphine from the auranofin analog, triisopropylphosphine(2,3,4,6-tetra- $O$-acetyl-1-thio- $\beta$-Dglucopyranosato-S)gold(I), via a protein-bound phosphonium intermediate. J. Am. Chem. Soc. 1994, 116, 2254-2260.

15. Hill, D.T.; Isab, A.A.; Griswold, D.E.; DiMartino, M.J.; Matz, E.D.; Figueroa, A.L.; Wawro, J.E.; DeBrosse, C.; Reiff, W.M.; Elder, R.C.; et al. Seleno-Auranofin (Et3PAuSe-tagl): Synthesis, Spectroscopic (EXAFS, ${ }^{197} \mathrm{Au}$ Mossbauer, ${ }^{31} \mathrm{P},{ }^{1} \mathrm{H},{ }^{13} \mathrm{C}$, and ${ }^{77} \mathrm{Se}$ NMR, ESI-MS) Characterization, Biological Activity, and Rapid Serum Albumin-Induced Triethylphosphine Oxide Generation. Inorg. Chem. 2010, 49, 7663-7675.

16. Lin, F.L.; Hoyt, H.M.; van Halbeek, H.; Bergman, R.G.; Bertozzi, C.R. Mechanistic investigation of the Staudinger ligation. J. Am. Chem. Soc. 2005, 127, 2686-2695.

17. Woehrle, G.H.; Hutchison, J.E. Thiol-functionalized undecagold clusters by ligand exchange: Synthesis, mechanism, and properties. Inorg. Chem. 2005, 44, 6149-6158.

18. Boerzel, H.; Koeckert, M.; Bu, W.; Spingler, B.; Lippard, S.J. Zinc-Bound Thiolate-Disulfide Exchange: A Strategy for Inhibiting Metallo-ß-Lactamases. Inorg. Chem. 2003, 42, 1604-1615.

19. Acharige, A. Reactions of Sulfur Compounds with $\mathrm{Zn}(\mathrm{II}), \mathrm{Au}(\mathrm{I})$, and $\mathrm{Hg}(\mathrm{II})$ and Metal Linker Polyaniline Electrodes for Energy Storage. Ph.D. Thesis, University of Maine, Orono, ME, USA, May 2011.

20. Binotti, B.; Macchioni, A.; Zuccaccia, C.; Zuccaccia, D. Application of NOE and PGSE NMR methodologies to investigate non-covalent intimate inorganic adducts in solution. Comments Inorg. Chem. 2002, 23, 417-450.

21. Ricci, J.S.; Bernal, I. Crystal structure of $\alpha$-bis( $p$-nitrophenyl) disulfide. J. Am. Chem. Soc. 1969, 91, 4078-4082.

22. Allen, F. The Cambridge Structural Database: A quarter of a million crystal structures and rising. Acta Crystallogr. Sect. B 2002, 58, 380-388.

23. Narayanaswamy, R.; Young, M.A.; Parkhurst, E.; Ouellette, M.; Kerr, M.E.; Ho, D.M.; Elder, R.C.; Bruce, A.E.; Bruce, M.R.M. Synthesis, structure, and electronic spectroscopy of neutral, dinuclear gold(I) complexes. Gold(I)-gold(I) interactions in solution and in the solid state. Inorg. Chem. 1993, $32,2506-2517$. 
24. Isab, A.A.; Sadler, P.J. A ${ }^{13}$ C Nuclear Magnetic-Resonance Study of Thiol-Exchange Reactions of Gold(I) Thiomalate (Myocrisin) Including Applications to Cysteine Derivatives. Dalton Trans. 1982, 135-141.

25. Uson, R.; Laguna, A.; Laguna, M.; Briggs, D.A.; Murray, H.H.; Fackler, J.P. (Tetrahydrothiophene) Gold(I) or Gold(III) Complexes. In Inorganic Syntheses; John Wiley \& Sons, Inc.: Hoboken, NJ, USA, 2007; pp. 85-91.

26. Bordwell, F.G.; Hughes, D.L. Thiol Acidities and Thiolate Ion Reactivities toward Butyl Chloride in Dimethylsulfoxide Solution-The Question of Curvature in Bronsted Plots. J. Org. Chem. 1982, $47,3224-3232$.

(C) 2015 by the authors; licensee MDPI, Basel, Switzerland. This article is an open access article distributed under the terms and conditions of the Creative Commons Attribution license (http://creativecommons.org/licenses/by/4.0/). 